\title{
O simbolismo e o boto na Amazônia: religiosidade, religião, identidade*
}

\author{
Raymundo Heraldo Maués**
}

Em trabalhos anteriores, ao tratar da identidade amazônica, tenho algumas vezes feito uma afirmação que considero adequada - tendo sempre, porém, o cuidado de enfatizar que não se deve generalizar uma visão homogeneizadora para esta grande região (e, por isso, muitas vezes, prefiro falar em Amazônias, no plural). Essa afirmação refere-se mais especificamente àquela parte da Amazônia onde nasci e onde vivo - e que mais conheço -, a Amazônia Oriental, na qual penso existirem três elementos fundamentais componentes dessa identidade: em primeiro lugar, a Cabanagem, grande revolta popular que eclodiu na primeira metade do século XIX, cuja memória ainda hoje está presente entre as populações das áreas interioranas nas quais ocorreu; em segundo, a festa de santo do catolicismo popular e, especialmente, o Círio e a Festa de Nossa Senhora de Nazaré, a maior concentração religiosa de todo o Brasil num único dia, ocorrida todos os anos em Belém, no segundo domingo de outubro; e, em terceiro lugar (mas não menos importante), o encantado ou bicho do fundo, personagem mítico que está associado à pajelança cabocla, estudada por folcloristas, historiadores e antropólogos, em várias regiões da Amazônia, sobretudo em cidades, vilas e povoações do interior.

* Trabalho apresentado na Mesa Redonda "História Oral e Religiosidade", durante o VIII Encontro Nacional de História Oral, no período de 02 a 05 de maio de 2006, em Rio Branco-AC. Agradeço o convite formulado pelos organizadores do encontro e os comentários e observações feitas pelos participantes do evento.

** Professor do Departamento de Antropologia da Universidade Federal do Pará. 
Quanto a este personagem - o encantado -, deve ser dito, desde logo, que sua presença marcante na Amazônia foi bem notada pelo poeta gaúcho Raul Bopp, que o imortalizou nos versos do conhecido poema Cobra Norato.

Neste trabalho, pretendo tratar exatamente sobre uma forma de encantado, que é o boto, personagem de tantas histórias populares na região, fazendo parte não apenas do folclore regional - no sentido de registro escrito e erudito dessa manifestação, por folcloristas, escritores de ficção e outros intelectuais -, mas concretamente das lendas e dos mitos (sempre atualizados) das populações rurais e urbanas, os quais estão associados a essa forma de prática xamanística a que me referi acima, chamada por muitos de pajelança cabocla, que possui componentes de ordem mágico-religiosa e, ao mesmo tempo, constitui uma das formas de medicina mais populares entre populações rurais e de origem rural desta região.

Permitam-me, porém, antes de prosseguir, fazer algumas considerações sobre religião e religiosidade, já que o título desta mesa contempla esta última expressão. O Dicionário Aurélio Eletrônico - Século XXI, que tenho em meu computador, assim define esses termos:

Religião. Crença na existência de uma força ou forças sobrenaturais, considerada(s) como criadora(s) do Universo, e que como tal deve(m) ser adorada(s) e obedecida(s). A manifestação de tal crença por meio de doutrina e ritual próprios, que envolvem, em geral, preceitos éticos.

Religiosidade. Qualidade de religioso. Disposição ou tendência para a religião ou as coisas sagradas. Escrúpulos religiosos. (Grifo meu).

Os sociólogos e antropólogos, a partir de Émile Durkheim, vêm considerando a religião mais ou menos nesses termos, acentuando os aspectos ligados ao sagrado, à crença, ao ritual e aos preceitos éticos, para um conjunto de fiéis que partilham dos mesmos e, por isso, constituem uma igreja. Seguindo o grande mestre francês, esses estudiosos levam a 
sério a premissa de que "não existem religiões falsas", pois todas elas respondem, de alguma maneira, aos anseios e aspirações do grupo de pessoas que a elas adere. Mas a diferença entre religião e magia, na qual esta se distinguiria daquela por não ter igreja, hoje já não possui o mesmo peso, mesmo porque, muito freqüentemente, as religiões introduzem a magia em seus rituais. Isto não é reconhecido por seus adeptos, que tendem, ao contrário, a considerar como magia somente a religião dos outros, especialmente se pertencente a povos dominados, ou se praticada por classes ou categorias subalternas dentro da estrutura de uma mesma sociedade (cf. a respeito Durkheim, 1979; Mauss e Hubert, 1974; e Fernandes, 1982).

Essa atitude preconceituosa também se manifesta de outra forma: ela é expressa no costume de chamar de "religiosidade" à religião dos outros, como bem aparece na definição do Aurélio: "escrúpulos religiosos". Não se agride o outro de forma acintosa, chamando sua religião de magia, mas recusa-se lhe conceder o status de religião, porque, de fato, se considera que a mesma é falsa e inferior, ou produto de "superstição", outra palavra do vocabulário etnocêntrico dessas pessoas, que se consideram as seguidoras da "verdadeira" fé e, conseqüentemente, da "verdadeira" religião. Assim, pensam elas: "eu tenho religião, os outros (especialmente o povo humilde) possuem religiosidade".

Os primeiros antropólogos e cientistas sociais que se interessaram pelo estudo da religião tentaram formular explicações para a crença na existência de seres espirituais, associando essa crença, nas populações ditas "primitivas", a experiências que os seres humanos vivenciam, como o sono, o sonho, a síncope, a catalepsia e a morte. No sono, na síncope e na catalepsia o corpo fica, especialmente nesta última, como que sem vida, para depois de algum tempo retornar à atividade. No sonho a pessoa se vê em vários lugares, muitas vezes como se viajasse, entra em contato com outras e fala, às vezes até com pessoas mortas. Na morte, é como se, no último momento, a pessoa exalasse, num sopro, alguma entidade misteriosa que está dentro dela. Tudo isso teria levado os primeiros homens e mulheres a pensarem numa substância interior, independente do corpo, que o anima e lhe sobrevive. Essa alma, comum aos seres humanos e aos animais, acabou sendo pensada também como existente para todos os seres, inclusive os inanimados. Aos poucos, porém, com a evolução do pensamento religioso, teriam surgido novas idéias: a de almas ou seres 
espirituais independentes dos seres materiais, o que conduziu a se pensar nos deuses; primeiramente um conjunto heterogêneo de deuses e espíritos, relacionados especialmente com as forças da natureza, depois a idéia de um ser supremo, superior a todos os deuses e, finalmente, a idéia de um deus único, que não eliminou, porém, a noção de vários seres espirituais independentes, alguns deles agora pensados como anjos, santos, espíritos de luz ou das trevas (neste caso, demônios).

Essas noções evolucionistas, preocupadas com origens, no sentido de como as coisas tiveram começo, estão hoje distantes das preocupações dos cientistas sociais, até mesmo porque envolvem, mais do que o conhecimento científico (que se baseia nas provas), o apelo, ao contrário, à imaginação e àquilo que seus críticos chamaram de "história conjectural". Há uma outra forma de pensar em origens, no sentido daquilo que está sempre presente, e que constitui o elemento fundamental para a existência de um dado fenômeno. Assim, em todas as sociedades humanas, encontramos a distinção entre aquilo que é sagrado e profano. O sagrado consistindo naqueles elementos geralmente (mas nem sempre) ligados a entidades sobrenaturais e objetos a elas relacionados, que são mantidos como interditos e separados, sendo na maioria das vezes objeto de respeito e de culto. O profano como o contrário disso tudo, o referente aos seres e objetos da vida cotidiana, aquilo que é comum, que é corriqueiro. Essa distinção está na base ou origem da religião e da magia. ${ }^{1}$

Por outro lado, a religião e a magia (duas faces de uma mesma moeda), têm a ver com o sentimento (não é por acaso que, para muitas religiões, a virtude primordial é o amor), sentimento esse que é exacerbado nas manifestações coletivas. Assim, por exemplo, em minha cidade, Belém, onde vivo há tantos anos - embora nela não tenha nascido -, quando celebramos nossa festa religiosa mais importante, o Círio de Nazaré, essas manifestações de sentimento e exaltação emocional aparecem com grande evidência, surgindo nas atitudes daqueles que participam da festa, especialmente no momento em que contemplam a passagem do objeto

1 Essa distinção é, no entanto, de caráter teórico e metodológico, não podendo ser pensada rigidamente. O próprio Durkheim (1979), que a formula, mostra como pode existir certa "contaminação" do profano pelo sagrado. A questão é discutida de forma mais clara e sofisticada em Mauss e Hubert (1974). No catolicismo popular brasileiro é muito claro como as concepções de sagrado e profano diferem entre sacerdotes e leigos, especialmente leigos praticantes do catolicismo popular. 
maior de devoção dos fiéis, a imagem da Virgem de Nazaré em sua berlinda, simbolizando todo esse sagrado onde as pessoas condensam sua fé e suas esperanças.

Condenam-se, freqüentemente, os chamados "excessos" de devoção, aquelas manifestações em que o numinoso é altamente potencializado, ou, de outro lado, as manifestações do "profano" na festa, combinações de elementos que já permitiram ao melhor romancista paraense, Dalcídio Jurandir, chamar o Círio de "carnaval devoto": "Na manhã do Círio, à janela, viu aquela massa meio infrene, numa espécie de Carnaval Devoto, tirando a Santa do seu bom sono na Sé, trazendo-a na Berlinda, como num carro de terça-feira gorda" (Jurandir 1960, apud Alves 1980, p. 9). Não será, porém, das próprias características da festa religiosa católica, como fato social, em que as emoções e o apelo ao lúdico podem chegar a um grau elevado de exacerbação, que advêm desses mesmos fatos? Por outro lado, o esforço controlador que a Igreja Católica, como instituição, exerce no sentido de disciplinar a festa, não é próprio também deste mesmo jogo de ações, reações e contra-reações que mantém vivo o catolicismo na cultura popular?

Falei, em outro lugar, de uma tensão constitutiva do catolicismo, que ocorre entre as instâncias popular e oficial dessa forma concreta de religião em nosso meio social. Procurei então mostrar que, a despeito da permanente tensão entre elas, essas instâncias são complementares entre si, uma não podendo existir sem a outra (Maués, 1995). O Círio é um dos momentos em que isso se expressa com plenitude, nessa imensa manifestação de fé popular que não pode deixar indiferente nenhum segmento da população paraense, mesmo aqueles que são adeptos de religiões diferentes do catolicismo.

Agora, após essas considerações um tanto longas, passo a tratar das questões relativas ao boto, embora não possa me ater somente a elas, pois essa temática tem relação com muitos outros aspectos da vida social e das representações e ideologias (num sentido amplo) das populações desta grande região. São muito conhecidas as lendas sobre o boto na Amazônia. A principal delas costuma enfatizar a sua capacidade de sedução sobre as mulheres, quando se transforma num "belo rapaz", que aparece nas festas 
do interior. Como será retomado adiante, com maiores detalhes, o tema é muitas vezes abordado, nas cidades, em tom de troça ou de malícia, enfatizando-se a pretensa "ingenuidade" ou "ignorância" do homem do interior. Em minha própria pesquisa, desenvolvida na chamada região do Salgado - que compõe uma parte do litoral e do nordeste paraense - pude encontrar vários relatos a respeito de botos machos e fêmeas ("botas"), capazes de exercer sedução ou fascínio sexual sobre homens e mulheres. Uma das narrativas mais típicas, referente ao boto macho, cujo resumo aqui reproduzo, é a seguinte:

O "fato" ocorreu há muitos anos, segundo o informante que fez o relato. Maria ${ }^{2}$ era uma jovem de 17 anos, filha de uma viúva chamada Raimunda, que morava numa comunidade próxima de Itapuá (povoação de pescadores do litoral paraense, onde iniciei minha pesquisa sobre o tema). Tinha dois irmãos adultos, Francisco e Antônio. Sua mãe começou a notar que a filha estava exageradamente pálida ("amarela") e, embora a moça escondesse o fato, havia mais de um mês que não ficava menstruada. A mãe procurou então o mais importante pajé da redondeza, chamado Procópio Souza, já falecido, e que morava em Itapuá. Depois de ouvir a estória contada pela mãe da moça, o pajé disse que ela tivesse muito cuidado, pois podia ser que fosse um "boto encantado" que estivesse "namorando" sua filha.

Por instrução do pajé, os irmãos de Maria se colocaram, no princípio da noite, escondidos junto ao porto, com suas espingardas carregadas. Depois de algum tempo, viram um movimento na água e, sem que nenhuma embarcação tivesse chegado ao porto, um rapaz todo vestido de branco começou a subir a pequena escada ali existente, para alcançar a terra. Francisco e Antônio não hesitaram: apontaram suas armas e abriram fogo. $\mathrm{O}$ rapaz de branco imediatamente se jogou nas águas do rio e desapareceu. No dia seguinte, alguns pescadores viram o cadáver de um boto boiando nas águas do furo da Laura (rio que fica em frente a Itapuá).

A moça permaneceu doente ainda por vários meses, mas, com o tratamento feito pelo pajé, acabou por se restabelecer. Mais tarde veio a

2 Todos os nomes utilizados são fictícios, com exceção do nome do pajé que fez o relato, cujo nome será informado na nota 3 . 
casar-se, teve vários filhos e passou a levar uma vida normal, como qualquer outra mulher de sua comunidade. ${ }^{3}$

Visando contribuir para a temática desta mesa, tento analisar essas lendas a partir da noção de ambigüidade, incorporando idéias relacionadas a pureza/impureza e tabu (alimentar, inclusive), como aparecem em trabalhos antropológicos clássicos de autores como Mary Douglas e Edmund Leach. Quero também chamar a atenção para o fato de que essas histórias referem-se sempre a uma espécie de tempo ou espaço mítico, no sentido de que nunca são situadas no presente (ocorreram, por exemplo, "faz muitos anos") ou localizadas no lugar onde mora o informante (foi sempre numa vila ou povoado distante). Daí porque me refiro a eles como lendas e/ou mitos (neste último caso, querendo referir-me a uma espécie de caráter sagrado que as mesmas possuem, como parte das concepções religiosas de muitas dessas pessoas que as narram).

Quando trabalhamos juntos em Itapuá, há vários anos atrás, Maria Angelica Motta-Maués ${ }^{4}$ e eu estávamos participando de um grande projeto sobre hábitos e ideologias alimentares em grupos sociais de baixa renda, financiado pela FINEP, desenvolvido conjuntamente pelos Programas de Pós-Graduação em Antropologia Social do Museu Nacional/UFRJ e da Universidade de Brasília. Esse projeto tinha sido proposto por Roberto Cardoso de Oliveira e Roberto da Matta, sendo coordenado, nos programas de pós-graduação onde se desenvolvia, por Klaas Woortmann e Otávio Velho. Vários estudantes de mestrado, nas duas instituições, dele participaram, com apoio financeiro, e isso servia para que nossas dissertações acadêmicas pudessem também ser financiadas. Alguns de nós, trabalhando na Amazônia, no Nordeste e no Centro-Oeste, pudemos nos dedicar ao estudo de tabus alimentares, especialmente à concepção muito popular sobre alimentos reimosos. Além de nós dois, Angelica e eu, também Mariza Peirano, numa praia do litoral do Ceará (Icaraî) e Carlos Rodrigues Brandão, no interior de Goiás, estudamos, entre outras coisas, a "reima" dos alimentos (cf. Brandão 1976; e Peirano 1975).

3 Este relato foi adaptado do que se encontra em Maués (1990, p. 54-55) e foi feito pelo principal pajé de Itapuá, na época, chamado "seu" Ramiro, um homem cego.

4 Trata-se de minha mulher, que também é antropóloga e colega de trabalho no Departamento de Antropologia da Universidade Federal do Pará. 
Para quem vive na Amazônia, a reima parece não ter segredos. Todos pensam saber o que são alimentos "reimosos" (ou "remosos") e o seu contrário. Reimosos são aqueles alimentos perigosos, que fazem mal, que são considerados tabus; muitos, especialmente nas cidades, e nas camadas intelectualizadas, consideram isso como bobagens ou ignorância de gente simples do interior. Sem entrar em maiores detalhes a respeito de nossa análise, devo dizer, entretanto, que a mesma acabou mostrando que se trata de um sistema bem mais complexo do que parece à primeira vista. E, além disso, que também possui um caráter universal. ${ }^{5}$

Assim, para entender o simbolismo da reima é interessante lembrar um sistema da mesma natureza, que é conhecido desde a Antigüidade e que podemos designar de "abominações" do Levítico e do Deuteronômio. Tratam-se dos chamados alimentos "impuros" da Torá judaica e que continuam a ser mencionados na Bíblia cristã. Se os compararmos aos alimentos considerados potencialmente reimosos na Amazônia, veremos que, salvo as diferenças resultantes de ambientes geográficos completamente diversos, há muitas semelhanças entre eles. São reimosos ou impuros: o porco, os peixes de pele (e "de lixa" ou "de casco", como se diz no litoral paraense), o camarão, o caranguejo e vários outros. Ainda hoje pessoas religiosas, como judeus (sobretudo se ortodoxos) e adventistas do sétimo dia, não encontram qualquer dificuldade para notar a relação entre as duas concepções. Como se explica esse simbolismo?

Tomemos o caso do porco. A Bíblia nos diz que ele é impuro por tratar-se de animal de casco fendido que não rumina (Levítico 11:7 e Deuteronômio 14:8). Nada é dito sobre andar na lama, ser um animal "sem higiene", transmitir doenças aos homens e outras características "próprias" dessa espécie. O que é dito, na verdade, com outras palavras, é que ele é um ser vivo que foge ao esquema geral de classificação, culturalmente adotado entre os judeus da época, para sua categoria. Animais de casco fendido, como o boi e a cabra, ruminam, mas o porco é anômalo, ambíguo, não rumina, mesmo tendo o casco fendido. Ora, tudo o que é ambíguo, estranho, fugindo ao esquema geral de classificação de sua

5 Para uma visão sintética dos resultados dessa investigação, cf. Maués e Motta-Maués (1978). Uma parte do relatório apresentado à FINEP foi transformada em livro (Motta-Maués e Maués, 1980). Quem desejar conhecer o conjunto dos resultados dessa pesquisa poderá também consultar o relatório final elaborado por Klaas Woortmann, que é facilmente acessível na internet (Woortmann, 1978). 
categoria, pode ser considerado anormal, impuro, reimoso, do ponto de vista simbólico. E isso acontece com todos os animais impuros do Antigo Testamento, bem como com todos os animais potencialmente reimosos na Amazônia.

E, justamente aqui, vem o ponto que desejo melhor enfatizar, nesta intervenção: isso acontece também com um animal extremamente ambíguo de nossa região, o boto, que é um mamífero em forma de peixe, que vive nas águas. Posso então dizer que, certamente, em parte por isso, há tantos mitos e lendas a seu respeito. E, também por isso, o boto constitui um tabu alimentar inconsciente (ninguém ao menos concebe a possibilidade de comer sua carne), mas, ao mesmo tempo, é visto como um símbolo sexual, um objeto de desejo, tanto dos homens (o boto fêmea, a "bota", como dizem), como das mulheres (o boto macho, transformado em um belo rapaz). Se não pode ser comido como alimento, é pensado, pelo menos no mito, como parceiro sexual (outra forma de "comida"), mas ao mesmo tempo é extremamente perigoso, pois pode levar à morte seus parceiros humanos, cujo sangue ele suga, como uma espécie de vampiro (cf. Douglas, 1976, Leach, 1983a e 1983b, Maués, 1990 e Maués e Motta-Maués, 1978).

No caso dos homens - embora haja relatos esparsos de relações "homossexuais" com o boto macho -, o verdadeiro objeto de desejo é representado pela "bota", não havendo, neste caso, aparentemente, uma explícita conotação mística ou sobrenatural. Há muitos relatos a respeito de pescadores que, casualmente, apanham fêmeas de boto em suas redes e, em algumas situações, copulam com elas. Esses relatos enfatizam o enorme prazer experimentado pelo homem, a ponto de ser necessário às vezes afastá-lo à força daquele ato, caso contrário ele corre o risco de morrer de prazer e exaustão. Mulheres belas e sexualmente atrativas podem ser comparadas a "botas", como aparece num dos melhores livros de Dalcídio Jurandir, Marajó, quando relata os devaneios de um personagem a respeito da heroína do romance:

Orminda era mulher para andar nas histórias, ficar nas modinhas, na beira dos trapiches, na lembrança dos homens, pensava o sírio. Lenda que não se podia esquecer mais. Também ouvira uma vez um canoeiro soltar no trapiche a mesma confissão surpreendente e misteriosa: 
- Orminda é boa que só bota. Da feita que um infeliz cai naquele

bicho só arrancando à força. (Jurandir 1992, p. 187)

Os relatos que se referem, porém, à sedução de mulheres por botos, dizem sempre respeito aos encantados, que são pensados como seres humanos vivos, iguais a todos os outros, mas com a diferença de que possuem poderes sobrenaturais, pela sua condição "liminar" de encantados. Nas crenças populares amazônicas há duas categorias de encantados: do fundo e da mata. Estes últimos têm escassa importância na região do Salgado, onde também a mata é pouco importante, reduzindo-se apenas a duas personagens, referidas como "anhanga" e "curupira" (sempre no gênero feminino, diferentemente do que ocorre no uso comum, em português). Nas áreas litorâneas (Marajó, Salgado, Bragantina), os encantados mais importantes são os do fundo que, por isso, são também conhecidos como "bichos do fundo", quando se manifestam sob a forma de animais aquáticos. São também chamados de "oiaras" (aproximadamente as mesmas iaras, denominação usual no resto do Brasil e também nas principais cidades amazônicas), quando surgem nas praias e nos manguezais, sob forma humana, procurando atrair as pessoas para suas moradas, no fundo (os chamados “encantes"). Manifestam-se também, desta vez de forma invisível, quando se incorporam nos pajés, curadores ou xamãs, com a finalidade principal de participar de seus rituais de cura - e, neste caso, são considerados benéficos e chamados de "caruanas". ${ }^{6}$

Os encantados aparece na figura de bicho [...]. É gente, mas é do fundo, é uma pessoa imitando um bicho [...]. Mora nos rio, nos igarapé. (Pescador de Itapuá)

Gente do encante se vira em tudo, se vira numa cobra, num boto, num peixe quarqué [...]. Bicho é isso que se fala, mas o encantado se vira em tudo e o bicho muitas vez é uma gente do encante, às vez pode que queira fazê o mal, ou queira fazê o bem. (Pajé de Itapuá, pescador aposentado)

6 Pode-se, é claro, pensar que, aqui, há também um evidente processo de antropomorfização desses animais presentes na natureza exuberante da Amazônia, mas não desejo, agora, privilegiar esta questão. Chamo apenas a atenção para o fato de que existe um jogo de alternâncias entre a forma humana e a animal, assim como também entre visibilidade e invisibilidade, o que sempre me deixou bastante curioso. 
O "boto encantado" - como foi descrito no relato resumido mais acima - apresenta-se diante de suas vítimas sob forma humana, seduzindo-as e mantendo relações sexuais com elas. Em seguida dirige-se ao rio, nele mergulhando e desaparecendo, já sob a forma de boto. Durante o ato sexual, age como uma espécie de vampiro, sugando o sangue da mulher:

Quando ele pega a mulher pra fazer o serviço é naquele grau que vai passando o sangue dela pra ele. Nela não fica nada dele, porque se ficasse o sangue dele nela, ela não ia ficando amarela. De cada vez que ele se une com ela, ele vai tirando. (Pajé cego de Itapuá, o mais importante do lugar)

Em conseqüência, a mulher fica cada vez mais anêmica e pode vir a falecer, caso seus parentes não tomem uma providência drástica, que é a de esperar o boto à noite, de tocaia, para matá-lo, no momento em que tenta fugir pelo rio; mesmo assim, como vimos, a mulher deverá ser conduzida ao pajé que, através de várias sessões de cura, irá tratá-la para afastar o encantado e propiciar o restabelecimento de sua saúde. Retomarei adiante essa forma de tratamento, para uma descrição mais detalhada.

Os encantados são seres ambíguos que, assim como podem curar e praticar o bem, podem também provocar doenças e "malinar" com as pessoas (isto é, provocar o mal, até mesmo a morte). As doenças por eles provocadas são, principalmente, o ataque de boto, a flechada de bicho e o mau olhado. $\mathrm{O}$ ataque de boto, como vimos, tem como agente causal um encantado do fundo (caruana ou oiara) do sexo masculino. Ele se utiliza (ou se disfarça sob a forma) de um boto, que se apresenta como um belo rapaz, sempre com um chapéu na cabeça e todo vestido de branco. Seus motivos são a maldade e desejo o sexual, sendo que a vítima não pode resistir-lhe. A própria vítima pode ter provocado o ataque, por não ter tomado certas precauções necessárias para evitá-lo. O fato é também interpretado como um descuido da parte dos parentes da mesma (marido, irmãos, pais etc.), que não tiveram o cuidado de vigiá-la.

A corrente do fundo é provocada por uma categoria específica de encantados, os caruanas. A causa instrumental, como no caso da intrusão por espírito, é a possessão: o agente se apodera do corpo da vítima. Há, porém, uma diferença no fenômeno de possessão em relação ao caso de intrusão por espírito: no caso da corrente do fundo, o caruana se "incorpora" 
completo em sua vítima, usando tanto a sua própria matéria como o seu espírito, embora permanecendo invisível, já que o encantado ou caruana não é um morto, mas um encantado. ${ }^{7}$ Não obstante, não existe a intenção de provocar o mal, apesar de que ele é causado, enquanto a pessoa atingida não procurar tratamento. A motivação do agente é o "agrado", isto é, o caruana escolhe aquela pessoa por gostar dela, para poder manifestar-se. A pessoa não pode resistir por si mesma e, se procurar tratamento - que deve ser feito com um pajé ou curador - poderá, caso possua um dom autêntico, tornar-se também um xamã ou curador. Também no caso de ataque de boto, existe uma forma de "agrado" por parte do encantado, mas se trata - pelo menos na região do Salgado - da forma mais temida dessa manifestação afetiva, como vimos acima e será mais detalhado a seguir, inclusive ressaltando seu aspecto "reprodutivo", da ocorrência dos chamados "filhos de boto".

No caso de flechada de bicho, o agente causal é um encantado do fundo não especificado: pode ser um caruana ou uma oiara de qualquer sexo (embora as oiaras pretas, por sua "malineza", sejam as maiores responsáveis por essa doença). A causa instrumental é uma "flecha invisível" que o encantado atira sobre a vítima. Sua motivação (causa final) pode ser simplesmente a maldade; mas a causa final pode também depender de um descuido ou desrespeito por parte da vítima. Qualquer pessoa, ao passar por um rio ou pelo mangal (lugares onde costumam estar os encantados do fundo), deve adotar uma atitude respeitosa e "pedir licença" à "mãe do rio" (encantado que "governa" aquele local). A fórmula usual é a seguinte: "Dá licença, minha vó!". Caso a pessoa não faça isso por descuido ou, pior ainda, assuma uma atitude desrespeitosa nesses lugares, está sujeita a ser atingida por uma "flechada", que lhe provoca uma dor localizada em alguma parte do corpo, sendo considerada uma doença grave (ou "braba").

Quanto ao mau olhado de bicho, trata-se de uma doença provocada por qualquer tipo de encantado (do fundo ou da mata). A causa instrumental é o "fincamento de olho", isto é, o encantado, mesmo permanecendo

7 Evidentemente, não se pode pensar numa lógica das crenças e práticas religiosas nos mesmos termos da que é empregada nos assuntos práticos, na ciência ou na filosofia. Isso é bem ilustrado pela famosa frase atribuída a Tertuliano e utilizada por vários teólogos cristãos, entre os quais Agostinho e Lutero: "Credo quia absurdum est". 
invisível, fixa o olhar sobre a cabeça da vítima. Isto pode ocorrer por simples maldade ("malineza"), mas também pode ser provocado pela própria vítima, como no caso anterior. Assim, ao passar pela floresta ("mata"), como ao passar por um rio ou pelo mangal, é preciso "pedir licença" à "mãe do mato" (curupira) ou à "mãe do rio", conforme o caso (a fórmula é a mesma). Caso a pessoa não faça isso está sujeita a sofrer o "fincamento de olho" de um caruana, uma oiara, uma curupira ou anhanga, que lhe provocará a doença mau olhado de bicho, cujos sintomas são uma dor de cabeça constante, além de enjôo e vômito; não é, porém, considerada uma doença grave. O mesmo ocorre se assumir uma atitude desrespeitosa. No caso da mata, esse desrespeito pode ter uma forma especial para o caçador. As pessoas acostumadas a caçar não devem procurar matar um só tipo de caça. Caçador que só procura um tipo de animal (veado, por exemplo) pode ser atingido pelo mau olhado aplicado por uma anhanga, que se manifesta sob a forma de animal. ${ }^{8}$

Entre as doenças provocadas por encantados, o ataque de boto, que só atinge mulheres entre a menarca e a menopausa, pode ser prevenido de forma especial. Os habitantes de Itapuá, por exemplo, dizem que ninguém deve "mexer" com boto (isto é, admirá-lo, ofendê-lo, dirigir-se a ele, de alguma forma), porque isso pode trazer más conseqüências. Essa proibição se dirige especialmente às mulheres, pois aquele pode ser um "boto encantado" que, ao ser interpelado pela mulher, passa a se "agradar" dela. Por outro lado, a mulher menstruada deve evitar andar pelo rio, pois mulheres menstruadas sempre atraem a atenção dos botos. Caso isto não seja possível, levará sempre consigo um pedaço de alho, cujo cheiro tem a propriedade de "espantar" o boto encantado.

Tivemos oportunidade, minha mulher e eu, de assistir a um fato que nos chamou a atenção para o problema, durante nossa segunda visita a essa mesma povoação de Itapuá (julho de 1975). Viajávamos em uma canoa onde havia duas moças, que mais tarde disseram a minha mulher que na ocasião estavam menstruadas. De repente, começaram a aparecer vários botos nas proximidades. Imediatamente, as moças trataram de segurar

8 Anhangas e curupiras são encantados "malinos" e, delas, podem-se esperar outros tipos de maldade. Além de aplicar o mau-olhado, elas podem "mundiar" o caçador, isto é, fazer com que se perca na floresta. 
fortemente um pedaço de alho que traziam consigo. Inexplicavelmente, para mim, os botos desapareceram e não tornaram a surgir até o final da viagem.

Por outro lado, os parentes de uma mulher (pais, irmãos, marido) têm uma certa "responsabilidade" na prevenção dessa doença, devendo sempre estar vigilantes para evitar que ela mantenha encontros com desconhecidos e aconselhando-a a tomar todas as precauções necessárias contra os perigos que o boto representa.

Caso, porém, a mulher venha a ser vítima de ataque de boto, seu tratamento inclui, além da providência já descrita acima, de eliminar o boto a tiros, a participação em várias sessões xamanísticas realizadas pelo pajé. Esse tratamento inclui, também, segundo os relatos que coletei, a aplicação de passes (que não diferem muito, no tocante às técnicas corporais, dos passes do espiritismo kardecista) e da prescrição de receitas constantes de banhos, defumações e remédios fortificantes. Um informante pajé forneceu-me uma receita completa para o caso: a) nove banhos, com o uso de ingredientes de origem vegetal (da região), como a folha de balde, o capitiú, o araticu, o hortelãzinho, o curimbó, a mucura caá e o limpacorpo (este último, um banho industrializado, comprado no comércio da cidade de Vigia); b) nove defumações, a serem feitas na casa da paciente, utilizando caroço de uxi, talo de mandioca, caroço de tucumã, espinho muru-muru, espinho de quatimura, espinho de porco quandu, espinho de papa-terra, maniva de veado, tabaco de veado (ou tabacorana) e caroço de piquiá; c) cinco vidros de Biotônico Fontoura ou Elixir de Nogueira (remédios comprados em farmácias). A maioria dos ingredientes, tanto dos banhos como das defumações, tem perfume desagradável. Mesmo assim, alguns são considerados “cheirosos”. Há uma relação intencional entre mau cheiro e perfume nesses remédios populares, sendo o mau cheiro utilizado para afastar as entidades más ou perigosas e o perfume usado para atrair aquelas que são vistas como benéficas. ${ }^{9}$

9 Infelizmente, não foi possível estabelecer a correspondência dos nomes populares com os nomes científicos das plantas utilizadas, para poder permitir sua melhor identificação. 
Em outras regiões da Amazônia, fala-se de relações sexuais entre botos machos, metamorfoseados em belos rapazes, com mulheres por eles seduzidas, que podem, em conseqüência, conceber e gerar filhos "de boto", como se diz. Muitas vezes isso é contado, nas capitais e cidades mais importantes da Amazônia - e mesmo nas principais cidades da região do Salgado (entre informantes mais intelectualizados) -, em tom de troça, ou para ilustrar a ignorância e ingenuidade do "caboclo do interior", como para falar, também, da "esperteza" das moças que, com essas histórias, tentam justificar a gravidez que não podem explicar claramente. Apesar disso, nas áreas rurais da região do Salgado - que visitamos intensivamente, por vários anos - nunca ouvimos histórias sobre filhos de boto. Pelo contrário, como foi dito acima, o assédio sexual do boto é visto como perigoso e maléfico. A mulher fica "amarela", como dizem, para expressar que ela vai, a cada dia, ficando mais anêmica, já que o boto age como uma espécie de "vampiro", sugando-lhe o sangue.

Aqui facilmente se pode estabelecer uma relação dessas lendas com noções mais antigas, que vêm da Idade Média européia - e que devem ter sido trazidas para o Brasil pelos colonizadores da Amazônia -, a respeito de íncubos e súcubos, isto é, de entidades demoníacas capazes de manter relações sexuais com seres humanos. Curiosamente, nos processos inquisitoriais pesquisados por Luís Mott (1985) em Portugal, referentes ao período colonial brasileiro, verifica-se que uma das formas de descobrir o parceiro sexual demoníaco era perceber um orifício nas costas do íncubo, ou demônio do sexo masculino, que se deitava sobre a parceira com quem vinha copular. Este orifício claramente parece similar àquele que o boto, metamorfoseado em gente - mas, sendo, de fato, gente, "gente encantada" e não boto -, procura esconder na cabeça, com seu indefectível chapéu.

Pergunto, por outro lado, se naquelas narrativas a respeito de filhos gerados por botos, não se pode também vislumbrar traços de antigas crenças a respeito de cópulas entre deuses e mulheres mortais, gerando filhos divinos ou semidivinos, que existem em religiões antigas e modernas, inclusive (embora, de certo modo, sublimadas) no próprio cristianismo? Vale reafirmar, a respeito disso que, em todas as histórias a nós relatadas, na região do Salgado, fica claro que o boto sedutor não é um boto qualquer, um boto comum, mas um boto "encantado", isto é, não um mero ser da natureza, como qualquer outro, mas um "bicho do fundo", uma entidade sobrenatural específica, isto é, um ser humano, mas um ser 
humano especial, que vem do "encante", a morada dos encantados ou bichos do fundo, que têm uma presença tão conspícua no mapa cognitivo dessas populações. ${ }^{10}$

Para concluir estas breves notas, muito tentativas, de reflexão e análise a respeito destes temas amazônicos, que lidam também com gênero e pajelança, gênero e encantaria, gostaria de fazer ainda algumas reflexões a respeito do simbolismo que está presente nesses mesmos temas. Esses elementos simbólicos com que tratam os habitantes da Amazônia e, aliás, todos os seres humanos, dizem respeito ao pensamento mítico, mágico, mas também à arte, à poesia e àquilo que o grande antropólogo Claude Lévi-Strauss chamou de pensamento selvagem ou ciência do concreto. Trata-se de uma forma de conhecimento que coexiste com o que podemos chamar de ciência "moderna", na verdade não tão moderna assim, se concebida como forma de pensar que, para os etnocientistas (em quem Lévi-Strauss se fundamenta, em parte), está presente em todas as sociedades humanas, em todas as épocas (cf. Lévi-Strauss 1970). Por outro lado, lembrando ainda outro antropólogo famoso, cujas idéias já foram utilizadas acima, Edmund Leach, vale dizer que aquilo que, para nós, com nossos preconceitos de citadinos intelectualizados, parece uma bobagem de pessoas rudes do interior - de quem às vezes se chega talvez a suspeitar que não conheçam mesmo as teorias adequadas sobre a concepção e geração de crianças -, podem não ser bobagens, mas formulações e dogmas teológicos, que estão presentes em religiões do mundo inteiro, mesmo naquelas consideradas como as mais "racionais" ou intelectualizadas.

\section{Referências bibliográficas}

ALVES, Isidoro. O Carnaval Devoto. Um estudo sobre a festa de Nazaré, em Belém. Petrópolis: Ed. Vozes, 1980.

BRANDÃO, Carlos. Crenças e Costumes de Comida em Mossâmedes. Série Sociedades Rurais do Mato Grosso Goiano, v. 5. UFGO, Goiânia, 1976.

10 Não podendo aqui examinar, com detalhes, esse mapa cognitivo, refiro, no entanto, que o assunto é tratado, inicialmente, em Maués (1992, p. 221-225) e, de uma forma um pouco mais detalhada, também em Maués (1995, p. 249-258). 
DOUGLAS, Mary. As abominações do Levítico. In: Pureza e Perigo: Ensaios sobre as noções de poluição e tabu. São Paulo: Perspectiva, 1976, p. 57-74.

DURKHEIM, Émile. Les Formes Élèmentaires de la Vie Religieuse. Paris: P.U.F., 1979.

FERNANDES, Rubem César. Os Cavaleiros do Bom Jesus: uma introdução às religiões populares. São Paulo: Ed. Brasiliense, 1982.

JURANDIR, Dalcídio. Marajó. Belém: Cejup, 1992.

LEACH, Edmund. Aspectos antropológicos da linguagem: categorias animais e insulto verbal. In: MATTA, Roberto da (Org.): Edmund Leach: Antropologia. São Paulo: Ática, 1983 (a), p. 170-198.

. Nascimento Virgem. In: MATTA, Roberto da (Org.): Edmund Leach: Antropologia. São Paulo: Ática, 1983 (b), p. 116-138.

LÉVI-STRAUSS, Claude. O Pensamento Selvagem. São Paulo: Ed. Nacional, 1970.

MAUÉS, R. Heraldo. A Ilha Encantada: medicina e xamanismo numa comunidade de pescadores. Belém: UFPA, 1990.

. Catolicismo popular e pajelança na região do Salgado: as crenças e as representações. In: SANCHIS, Pierre (Org.). Catolicismo: Unidade religiosa e pluralismo cultural. Col. Catolicismo no Brasil Atual, v. 3. São Paulo: Loyola, 1992, p. 197-230.

Padres, Pajés, Santos e Festas: catolicismo popular e controle eclesiástico. Belém: Cejup, 1995.

MAUÉS, R. Heraldo; MOTTA-MAUÉS, M. A. O modelo da 'reima': representações alimentares em uma comunidade amazônica. Anuário Antropológico. v. 77, n. 2, p. 120-147, 1978.

MAUSS, Marcel; H. HUBERT. Esboço de uma teoria geral da magia. In: MAUSS, Marcel. Sociologia e Antropologia, v. I. São Paulo: EPU/EDUSP, 1974, p. 37-176.

MOTT, Luiz. Etnodemonologia: aspectos da vida sexual do diabo no mundo ibero-americano (séculos XVI ao XVIII). Religião e Sociedade, v. 12, n. 2, p. 64-90, 1985.

PEIRANO, Mariza. Proibições alimentares numa comunidade de pescadores. Brasília: Departamento de Ciências Sociais da Universidade de Brasília, 1975. Dissertação de Mestrado.

Resumo: Este trabalho discute as lendas e mitos sobre o boto na Amazônia, examinando seu simbolismo e tomando como aspecto central a questão da ambigüidade. Além disso, procura situar essas lendas e mitos no contexto religioso, de outras crenças e mitos, bem como práticas, relacionadas à religião popular, ao catolicismo e a uma espécie de culto xamânico que chamo de pajelança cabocla, forma de medicina muito difundida entre as populações rurais e de origem rural dessa região brasileira. Relacionado a isso, há uma breve discussão sobre identidade, que passa também por essas crenças e práticas populares.

Palavras-chave: Amazônia; boto; encantado; pajelança; religião; religiosidade.

Symbolism and the boto (river dolphin) in Amazon: religiosity, religion, identity 
Abstract: This paper discusses the legends and myths about the Amazonian river dolphin by examining their symbolism and selecting as the central aspect the issue of ambiguity. Furthermore, it tries to situate such legends in the religious context of other beliefs and myths, as well as practices related to popular religion, $\mathrm{Ca}$ tholicism and to a type of shamanic worship I call pajelança cabocla (shamanic healing), a very popular form of "medicine" among rural, and of rural origin, populations in this Brazilian region. It also includes a brief discussion - related to the aforementioned - about identity, which covers such popular beliefs and practices.

Keywords: Amazon; river dolphin; shamanic healing; religion; religiosity. 